\title{
Pelatihan Dasar Membuat Aplikasi Android App Inventor Pada Sekolah Menengah Atas Saint Siak Sri Indrapura
}

\author{
Bayu Febriadi*1, Loneli Costaner ${ }^{2}$, Guntoro $^{3}$ \\ 1,2,3Fakultas Ilmu Komputer, Universitas Lancang Kuning \\ ${ }^{3}$ Program Studi Teknik Informatika, Fakultas Ilmu Komputer, Universitas Lancang Kuning \\ *e-mail: bayufebriadi9@gmail.com ${ }^{1}$, $\underline{\text { lonelicostaner@unilak.ac.id }}^{2}$, guntoro@unilak.ac.id ${ }^{3}$
}

\begin{abstract}
Today's technology continues to grow rapidly which can be used to facilitate and support human activities, starting from the homework, business, marketing and office processes. So it takes knowledge to use technology-based facilities to improve human resources that are efficient for life independence. With the development of the world of digitalization technology is becoming evident before humans of this era, where in the past people for shopping and learning must come to the intended destination, but now people only stay at home or anywhere they can do their activities with just the touch of a finger. The ease of this facility is inseparable from the many Android-based applications to market products to be sold, both changing services, goods, and personnel. The condition of changing activities hard to soft activities is because the development of the digital era is very important for students to understand the development and training of Android-based applications in order to gain skills in designing Android-based applications open souce namely with an inventor app that can be used free of charge, its form visuals that make it easier for students to design and create android-based applications.
\end{abstract}

\section{Keywords: Technology, Android, inventor app}

\begin{abstract}
Abstrak
Teknolog saat ini terus berkembang pesat yang dapat dimanfaatkan untuk mempermudah dan mendukukang aktifitas manusia, mulai dari proses pekerjaan rumah, bisnis, pemasaran dan perkantoran. Sehingga butuh pengetahuan untuk menggunakan sarana sarana berbasis teknologi guna meningkatkan sumber daya manusia yang berdaya guna untuk kemandirian hidup. Dengan perkembangan teknologi dunia digitalisasi menjadi nyata dihadapan manusia era ini, dimana dahulu manusia untuk berbelanja maupun belajar harus datang ketempat tujuan yang dimaksud, namun sekarang manusia hanya tinggal dirumah atau dimana saja bisa melakukan aktifitasnya hanya dengan sentuhan jari saja. Kemudahan sarana ini tidak terlepas dari banyak nya aplikasi berbasis android untuk memasarkan produk yang akan dijual, baik beruba jasa, barang, maupun tenaga. Kondisi prubahan aktifitas secara hard kepada aktifitas soft ini dikarenakan perkembangan era digital ini sangat penting bagi para pelajar untuk memahami perkembangan dan latihan aplikasi berbasis android guna mendapatkan keterampilan dalam merancang aplikasi berbasis android berbasis open souce yaitu dengan app inventor yang dapat dugunakan secara gratis, bentuk nya visual yang memudahkan pelajar untuk merancang dan membuat aplikasi berbasis android.
\end{abstract}

Kata kunci: Teknologi, Android, app inventor

\section{PENDAHULUAN}

Sekolah menengah Atas (SMA) maupun yang setara merupakan jenjang pendidikan yang wajib diemban oleh setiap individu anak bangsa. Dimana masyarakat yang sudah mengeyam pendidikan hingga sembilan tahun akan memiliki pola pikir yang baik dan inovatif dari pada yang hanya berpendidikan sekolah menengah pertama atau bahkan tanpa mengenyam pendidikan. Sekolah sebagai tempat untuk menggali potensi diri sehingga perlu pengarahan optimal guna tercapainya visi misi sebuah lembaga pendidikan sehingga ketika mereka selesai dalam pendidikan mampu menjadi pribadi yang mandiri dan memiliki kepercayaan diri untuk berkontribusi ditengah masyarakat.

SMA Sains Tahfizh Islamic Center salah satu sekolah yang ada di kabupaten Siak sri indrapura berdiri pada tahun 2016 yang kini dipimpin oleh Bapak Ustad Toto Prasetyo, LC, 
dimana sekolah terletak ditempat yang sangat strategis Komplek Islamic Center. Kel. Kampung Rempak. Kec. Siak, Kabupaten Siak Provinsi Riau menjadi perhatian oleh banyak masyarakat.

Dalam menjalankan aktifitas pendidikannya sekolah sains tahfidz memiliki kurikulum tersendiri dalam menghasilkan lulusan yang terbaik, dimana sekolah ini memiliki pendidikan umum sebagaimana sekolah lainya namun ia juga menanamkan pengetahuan, hafidz qur'an dan teknologi. Sesuai dengan visi sekolah "Terwujudnya Peserta Didik yang Beriman dan bertaqwa kepada Allah, Tahfizh Al Qur'an. Menguasai ilmu pengetahuan dan teknologi, Cerdas Kreatif, Trampil, Mandiri Berwawasan Global serta peduli terhadap lingkungan hidup dan berbudaya melayu".

Setelah dilakukan observasi langsung kelapangan dan wawancara kepada pihak sekolah SMA Sains Tahfidz ditemukan beberapa kendala dalam mencapai visi misi sekolah guna meningkatkan kwalitas lulusan yang mandiri dan memiliki keterampilan dalam teknologi. Ilmu teknologi yang saat ini yang berkembang adalah aplikasi berbasis android dimana pada pertengahan tahun 2019 pengguna aktif android sebanyak 2.5 Miliyar dibanding dengan pengguna IOS yang hanya 1.4 Miliar pengguna perbulannya. Salah satu aplikasi yang mudah dan bersifat open source atau sumber terbuka membuat aplikasi berbasis android adalah APP Inventor, dimana aplikasi app inventor web ini hanya menggunkan visual block yang dapat dipelajari oleh siapa saja yang ingin membuat aplikasi berbasis android tanpa harus menguasai kode program (Efendi, 2018), (Syaputrizal \& Jannah, 2019), (Fitri Astuti \& Marisa Khairina, 2014), (Sari \& Hardyanto, 2016), (Putra \& Rosati, 2020), (Hamdi \& Krisnawati, 2011), (M Nang, Alkodri; Ayu, 2019), (Wihidayat \& Maryono, 2017), (Wirastuti, 2014), (Nababan, Kevin, \& Wijaya, 2019).

Berdasarkan uraian diatas yang merupakan hasil justifikasi tim IbM dan calon Mitra, maka didapatkan permasalahan yang dihadapi calon mitra sebagai berikut:

1. Calon mitra belum mengetahui program open souce dalam membuat aplikasi android

2. Calon mitra belum memahami cara merancang aplikasi android yang mudah dan menyenangkan

3. Calon mitra belum mengetahui cara mengupload aplikasi androdi ke playstore

\section{METODE}

\subsection{Khalayak Sasaran}

Sasaran kegiatan ini adalah siswa siswi sekolah sains tahfidz islamic center siak sri indrapura, mereka yang mengikuti adalah siswa siswi pilihan perwakilan kelas sebanyak 30 siswa.

\subsection{Prosedur Kerja}

Sosialisasi dan pelatihan dilakukan dengan mengikuti prosedur berikut ini:

a. Mengusulkan kegiatan Pengabdian Kepada Masyarakat ke LPPM

b. Mengurus dan menyiapkan segala kebutuhan administrasi.

c. Mengirim surat kerjasama untuk melaksanakan kegitatan pengabdian di sekolah.

d. Menyiapkan modul pelatihan

e. Melakukan sosialisasi dan pelatihan membuat aplikasi berbasis android.

f. Melakukan evaluasi terhadap keberhasilan Pengabdian Kepada Masyarakat

\subsection{Metode Pelaksanaa}

Metode pelaksanaan kegiatan pengabdian pada pelajar SMA Saint Islamic Center Siak dapat dilihat bapad bagan dibawah ini; 
1. Calon mitra mengetahui program open souce dalam membuat aplikasi android

2. Calon mitra belum memahami cara merancang aplikasi android yang mudah dan menyenangkan

3. Calon mitra belum mengetahui cara mengupload aplikasi androdi ke playstore
1. Memberikan pemahaman tentang pemprogaman android berbasis syntax program dan berbasis visual

2. Memberikan pelatihan membuat aplikasi android dengan pemrograman open source app Inventor

3. Memberikan pelatihan cara mengupload aplikasi android ke playstore

Gambar 1. Metode pemahaman teknologi pelatihan

\section{HASIL DAN PEMBAHASAN}

\subsection{Hasil Kegiatan}

Pengabdian masyarakat yang dilaksanakan pada sekolah SMA Saint Tahfizh Islamic Center berjalan dengan baik, berikut gambar proses pelaksanaan kegiatan pelatihan yang telah dilakukan selama 8 jam dilaboratorium komputer sekolah;

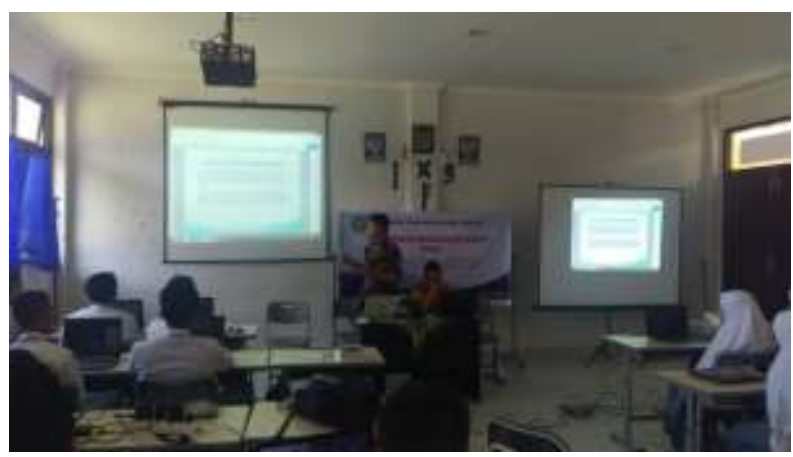

Gambar 2. Pemahaman APP Inventor android

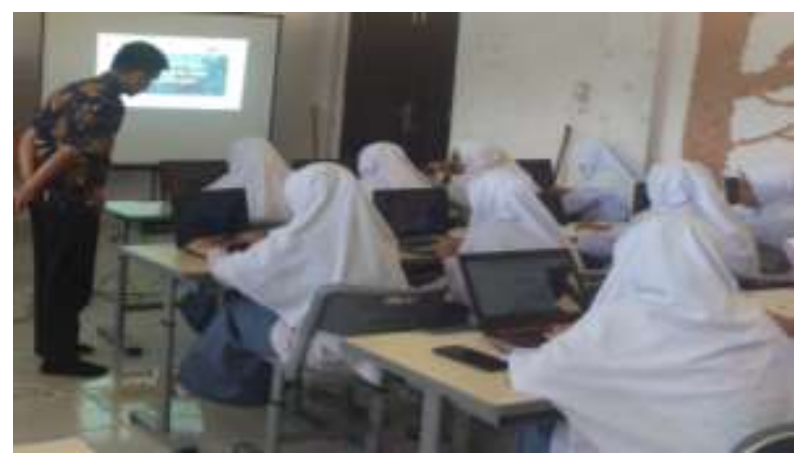

Gambar 3. Membuat account App Inventor

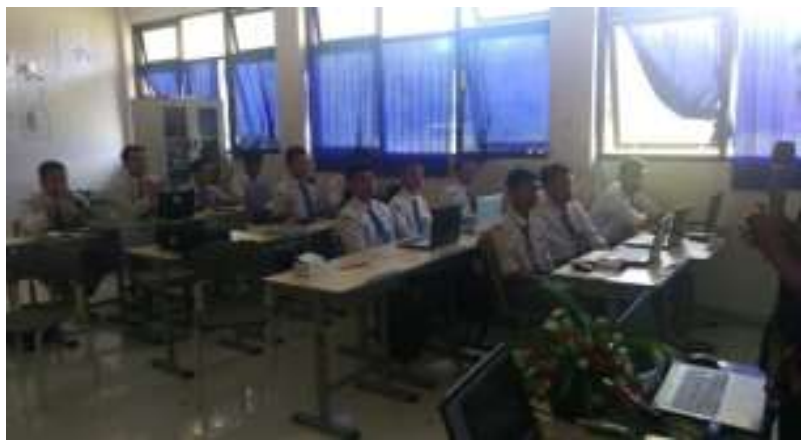

Gambar 4. Peserta mulai membuat aplikasi menggunakan app inventor 


\subsection{Pembahasan.}

Berikut pembahasan dalam pelatihan yang telah dilakukan selama 7 jam, dengan 30 peserta pelatihan, dengan test pemahaman sebelum pelatihan, kemudian memberikan pelatihan dengan modul hingga menjadi sebuah aplikasi sederhan berbasis android dan trakhir peneliti memberikan umpan balik untuk mengetahui peningkatan pemahaman peserta pelatihan dengan instrument quisioner, berikut penjelasanya;

Tabel 1. Presentasi pretest (sebelum pelatihan mendapatkan pemahaman 13.6\%)

\begin{tabular}{clcc}
\hline No & Pertanyaan & Pertanyaan (Ya) & $\%$ Pertanyaan (Ya) \\
\hline 1 & K1 & 27 & $90 \%$ \\
2 & K2 & 0 & $0.0 \%$ \\
3 & K3 & 2 & $6.7 \%$ \\
4 & K4 & 0 & $0.0 \%$ \\
5 & K5 & 5 & $16.7 \%$ \\
6 & K6 & 0 & $0.0 \%$ \\
7 & K7 & 0 & $0.0 \%$ \\
8 & K8 & 0 & $0.0 \%$ \\
9 & K9 & 0 & $0.0 \%$ \\
10 & K10 & 0 & $0.0 \%$ \\
11 & K11 & 0 & $0.0 \%$ \\
12 & K12 & 0 & $0.0 \%$ \\
13 & K13 & 19 & $63.3 \%$ \\
Total & 53 & 176.7 \\
Rata rata & 4.1 & 13.6 \\
\hline \multicolumn{7}{l}{ Tingkat pengetahuan sebelum pelatihan } \\
\hline
\end{tabular}

Tabel 2. Presentasi posttest (sesudah pelatihan mendapatkan pemahaman $86.4 \%$ )

\begin{tabular}{clcc}
\hline No & Pertanyaan & \% Pertanyaan (Ya) & \% Pertanyaan (Ya) \\
\hline 1 & K1 & 29 & 97 \\
2 & K2 & 19 & 63 \\
3 & K3 & 28 & 93 \\
4 & K4 & 30 & 100 \\
5 & K5 & 30 & 100 \\
6 & K6 & 28 & 93 \\
7 & K7 & 26 & 87 \\
8 & K8 & 30 & 100 \\
9 & K9 & 30 & 100 \\
10 & K10 & 2 & 7 \\
11 & K11 & 29 & 97 \\
12 & K12 & 27 & 90 \\
13 & K13 & 29 & 97 \\
Total & 337 & 1123 \\
Rata rata & 25.9 & 86 \\
\hline \multicolumn{7}{l}{ Tingkat pengetahuan setelah pelatihan } \\
\hline
\end{tabular}


Jumlah persentasi pengetahuan peserta pelatihan dengan rumus, Kuisioner $=($ Nilai rata rata / jumlah kuisioner) x nilai persentasi (100\%). Sehingga didapatkan pilihan "YA" 100\% dikarenakan seluruh peserta sangat memahami maksud seluruh (12) butir pertanyaan tersebut, sedangkan untuk peserta tidak memahami maksud 13 butir pertanyaan dengan persentasi $0 \%$. Total persentasi pengetahuan sesudah dilakukan pelatihan didapatkan $100 \%$ dimana hal ini menggambarkan bahwa peserta sudah memahami maksud pelatihan aplikasibasis android dengan catatan tetap dibawah pendampingan tim pelaksana. Untuk mengetahui kenaikan pengetahuan peserta dari sebelum mendapatkan pelatihan kemudian dilaksanakannya pelatihan penggunaan aplikasi app inventor dengan cara, \% Kenaikan = Jumlah persentasi pretest - Jumlah persentasi posttest maka dapat diterjemahkan $13.6 \%-86.4 \%=78.8 \%$. Sehingga dapat dilihat peningkatan pemahaman peserta dalam memahami cara membuat aplikasi berbasis android menggunakan app inventor dengan tingkat kenaikan $78.8 \%$, dapat dikatakan jumlah persentasi tersebut naik secara signifikan dari sebelum dilakukannya pelatihan dan sesudah dilakukan nya pelatihan. Hasil persentasi dapat dilihat pada gambar 12 berikut ini.

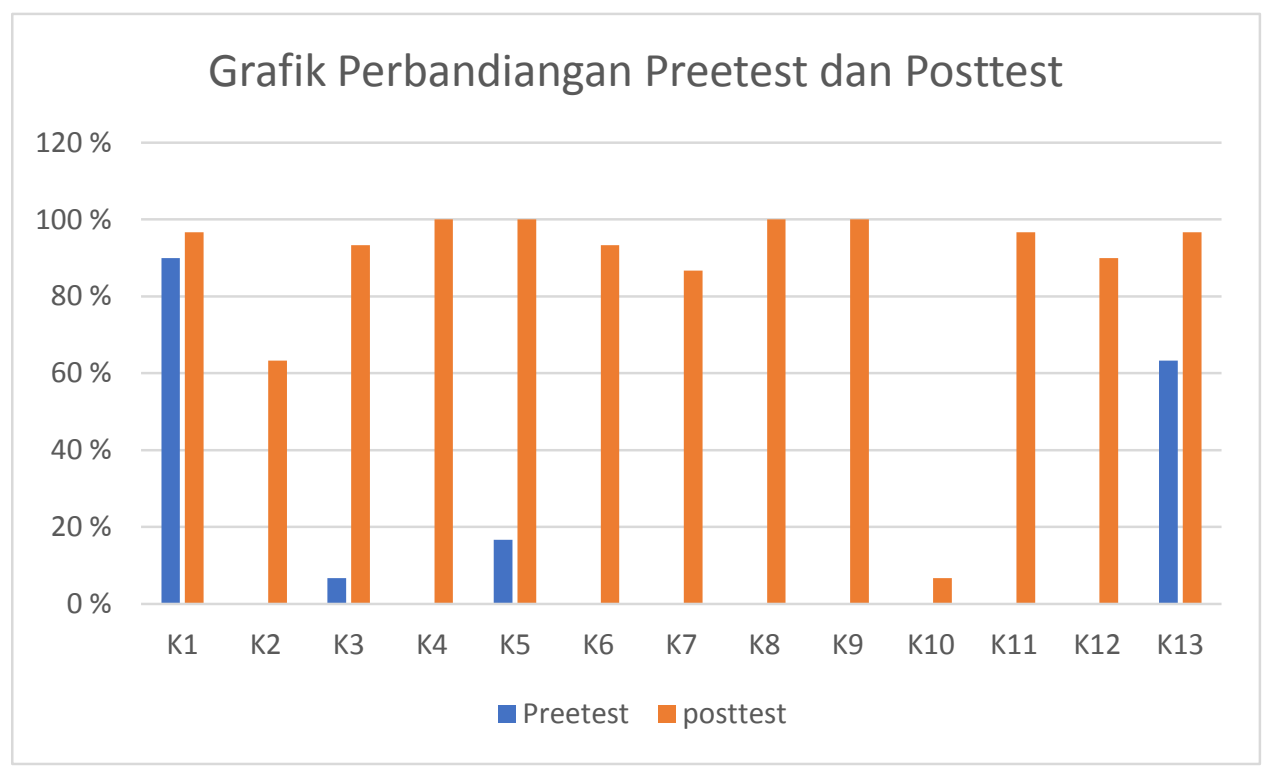

Gambar 5. Hasil perbandingan peningkatan pemahaman peserta

Gambar diatas menerangkan perbandingan tingkat pemahaman peserta sebanyak 30 orang peserta diawali dengan pretest (sebelum dilakukan pelatihan) dengan grafik berwarna biru dan posttest (sesudah dilakukan pelatihan) dengan grafik berwarna merah, dapat kita lihat secara kontras peningkatan pemahaman peserta terhadap pembuatan aplikasi berbasis android menggunakan app inventor yang yeng menunjukkan peningkatan secara signifikan. Pada butir $\mathrm{K} 2$, K4, K6, K7, K8, K9, K10, K11 dan K12 peserta yang sama sekali belum memahami namun setelah dilakukan pelatihan peserta memiliki peningkatan secara baik.

\section{KESIMPULAN}

Kesimpulan yang didapatkan dari hasil pengabdian pada pelajar SMA Saint Tahfidz Islamic Center Siak dapat ditarik sebegai berikut;

a. Bahwa tingkat pemahaman pelajar masih rendah tentang aplikasi berbasis android sebesar $13.6 \%$

b. Bahwa tingkat pemahaman peserta meningkat sebesar $86.4 \%$ setelah mendapatkan pelatihan

c. Bahwa tingkat kenaikan pemahaman pelajar dalam membuat aplikasi sebesar $78.8 \%$ 


\section{UCAPAN TERIMA KASIH}

Penulis mengucapkan terima kasih kepada pimpinan Fakultas Teknik dan Ilmu Komputer yang telah memberi dukungan financial terhadap pengabdian ini.

\section{DAFTAR PUSTAKA}

Efendi, Y. (2018). Rancangan Aplikasi Game Edukasi Berbasis Mobile Menggunakan App Inventor. Jurnal Intra-Tech, 2(1), 41.

Fitri Astuti, I., \& Marisa Khairina, D. (2014). Sistem Pencarian Rute Lokasi Menggunakan Global Positioning System Dan App Inventor Secara Visual. Informatika Mulawarman: Jurnal Ilmiah Ilmu Komputer (JIM), 2(9), 7-11.

Hamdi, G., \& Krisnawati. (2011). Membangun Aplikasi Berbasis Android "Pembelajaran Psikotes" Menggunakan App Inventor. JURNAL DASI, 12(4), 37-41.

M Nang, Alkodri; Ayu, P. (2019). Pengembangan Media Pembelajaran Berbasis Android Dengan APP Inventor Pada Mata Kuliah Bahasa Pemrograman. E-Tech, 01(00), 01-05. https://doi.org/10.1007/XXXXXX-XX-0000-00

Nababan, M., Kevin, \& Wijaya, A. (2019). Perancangan Aplikasi Member Fitnes Berbasis Android Menggunakan App Inventory. Jurnal Mantik Penusa, 3(2), 82-87. Retrieved from http://ejurnal.pelitanusantara.ac.id/index.php/mantik/article/view/567

Putra, W. I., \& Rosati, A. (2020). Perancangan Aplikasi Profil E-Book Fakultas Sains Dan Teknologi Universitas Karimun Berbasis Android. Jurnal TIKAR, 1(1), 44-53.

Sari, M. W., \& Hardyanto, H. (2016). Implementasi Aplikasi Monitoring Pengendalian Pintu Gerbang Rumah Menggunakan App Inventor Berbasis Android. Eksis, 09(1), 20-28.

Syaputrizal, N., \& Jannah, R. (2019). Media Pembelajaran Fisika Berbasis M obile Learning pada Platform Android Menggunakan Aplikasi App Inventor untuk Meningkatkan Kemandirian Belajar Peserta Didik. Natural Secience, 5(1), 800-809.

Wihidayat, E. S., \& Maryono, D. (2017). Pengembangan Aplikasi Android Menggunakan Integrated Development Environment (Ide) App Inventor-2. Jurnal Edutic, 4(1), 1-12. Retrieved from http://journal.trunojoyo.ac.id/edutic/article/view/3229

Wirastuti, A. A. K. A. I. G. A. K. D. D. H. N. M. A. E. D. (2014). Rancang Bangun APlikasi Pendataan Warga Banjar Berbasis Android. Jurnal SPEKTRUM, 1(1), 65-71. 